\title{
THE AUTHORITY OF VILLAGE GOVERNMENT IN AFFIRMING BORDER MANAGEMENT (CASE STUDY OF GALANG ISLAND DISPUTE)
}

\author{
Rina Yulianti ${ }^{1}$ \\ Iwan Permadi ${ }^{2}$
}

\begin{abstract}
Border Disputes related to territorial management between local Governments dominate the ongoing cases within the Ministry of Internal Affairs in Indonesia. This study aims to propose a model of a policy of border Disputes resolution using non-doctrinal legal research (socio-legal research). This research limited itself by looking at Galang Island, the which is disputed between the city of Gresik and Surabaya. To gain Appropriate analyzes, in depth interviews and secondary of data was conducted and collected both in Gresik and Surabaya. Furthermore, this research finds that the reason underpinned such Disputes lays on the weaknesses of village government in the territorial management proofing formally they have been doing. It is submitted that in forming and affirming border delimitation, Indonesian Act Number 6 year 2014 on Village jo Ministry of Internal Affairs Regulation number 114 year 2014 can used as legal base.
\end{abstract}

Keywords: Authority, Village Government, affirming, Border

\section{INTRODUCTION}

Indonesian Act No. 22 Year 1999

on Local Government Autonomy marks the beginning of an era in Indonesia, where local government was given broader authority and responsibility. The newest revision of the Act is Indonesian Act No. 23 Year 2014. This Act moreadopted principles, to which include democratic, equalization, fairness,

\footnotetext{
${ }^{1}$ Lecturer of Law Faculty, Trunojoyo University Faculty Of Law, email: abundarina@gmail.com
}

justice, specialization and the potential diversity of each local government within Indonesia. Legal implication of the enforcement of Indonesian Act No. 23 Year 2014 is broader authority of local government to manage natural resources within Reviews their territory, both in land and ocean.

Thus Spake border delimitation is crucial. Because this is such a border delimitation administration Affects not

\footnotetext{
2 Lecturer of Law Faculty, Brawijaya University
} 
only population issue, but also encourage Disputes resources management. General Allocation Fund (DAU / General Allocation Fund) as well as profit sharing is affected by how broad local government's terrotiry is.

Tus, this aspect is considered as stsrategic factor of border delimitation. For the purpose of this research, it should be Noted that local government include village government.

In fact the braoder the autonomy given by the local government, on border delimitation Increased Disputes. One of intereseting Disputes, roomates also the focus of this study was Disputes on Galang Island located between Gresik and Surabaya. Tus, it is submitted that the legal Tus reconstruction on border Disputes between local Governments is needed

Based on the above background, research questions is as follows: "To what extend the authority of village government in Determining border delimitation as a means to resolve border resolution Disputes between Gresik and Surabaya?"

\section{RESEARCH METHOD}

The type of study used in this research is socio legal research with empirical study and look at how the law works in society. This research is conducted in East-Java, especially in disputed areas, to which include Surabaya and Gresik.

Data used consists of primary and secondary data. Primary Data include filed study, interview and observation gained form local society living around the disputed areas. In addition to this, Also information gained from local government officers from villages level up to distric level as well as the relevant parties in the border involve; Disputes. Secondary whereas the data is gained through documentary study and the decision made by the local authority related to the border dispute resolution.

\section{RESULT AND DISCUSSION} Reasons and Implication of Border Dispute in Galang Island

The object of this study is Galang Island of 14 acres, having different history based on each of the local government versions. According to Karang KiringVillage, Galang Island was part of Java Island and due to abrasion, Galang Island was separated from Java. Whereas According to Romokalisari Village, Galang Island was found by university student in Surabaya 
along with local authority while conducting land surveys. It is not surprising that each of parties has disputed Reviews their own technical, legal and historical claim on their argumentations. Each party "claim to have rights" on the existence of Galang Island, which leads to a legal dispute. The following are argumentations of each local government:

a. Karang Kiring's argumentation: Aslimun, the Head of Karang KiringVillage Explains that historicaly the existence of Galang Island was a part of Java and separated due to abrasion. Along the way, there has been a land of certification given by the National Land Agency (BPN) to 7 villagers until it was owned by three business entity. ${ }^{3}$

b. The argument of Land Ownership Holder at Galang Island

PT Gantari Sandya Partner (GSM) juridicaly Considered as the only legal ownership of land certification issued by BPN through Gresik Land

${ }^{3}$ interviews with Karang Kiring Head of Village On May 15, 2015.

${ }^{4}$ http://www.publiknasional.com/index.php?opti on=com_content \&view=article\&id=1464:urukpantai-pt-gantari-sandya-mitra-diprotres-
Offices, over the Galang Island. PT GSM's ownership rights was based on merging many land certificate and now known as belongs to Tri Hanggo with certificate number $72 .{ }^{4}$

c. Argumentation of Surabaya Government

Legal Department of Surabaya Government re-affirming that Galang Island is included within Surabaya territory based on legal documents collected by the Department of Land and Building Surabaya. ${ }^{5}$

d. Arguments Regional Office of the National Land Agency and Spatial East Java

The BPN through the Office of East Java testified as follows: In 1978, the status of the land that is now standing Gantari Sandya factory owned by PT Mitra belonged 7 Karang Kiring figures in the name of Yahya, Mas'ud, Oyek, Kasbu, Daji, Wahyudin and Amali Umpung who cultivate land or now known coast with Galang Island, " In 1988 the land owned by 7 persons sold to 3 brothers namely Dorowati, Punta Surya and Surya

nelayan\&catid=36:jawa-timur, accessed on 8 Juni 2015

${ }^{5}$ Interviews with Mr. Maskur, Legal Department Staff of Surabaya Government, on June 9, 2015. 
Puntoro. In the same year, land ownership is merged into one with a certificate issued by the Office of Agricultural Province (BPN and Spatial Planning) of the number m44 into M71, M45 to 72, M46 to 72 are now passed on to the Tri Hanggo, and on the land is established factory PT Gantari Sandya Partners. Thus, according to the records office of the Office of BPN / Spatial East Java ownership of the land is lawful PT GSM. $^{6}$

e. Arguments East Java DPRD Commission A (period 20092014)

As we went to the East Java Provincial Parliament, and met by the deputy chairman of the period 20142019, Mr Kusnadi, SH., M. Hum., Galang Island issue has been handled by the Commission A and the Special Committee (Committee) East Java DPRD the period 2009-2014, and at that moment Mr Kusnadi still served as a committee member in charge of government and law. Here conveyed by Mr. vice chairman of what was done by the people's representatives in response to the case between the government of

${ }^{6}$ Interview with Analysis and dispute Resolution Officer Indonesian Land Authority East Java Province on 8 June 2015
Surabaya and Gresik District

Government, as follows:

Galang Island attention to the dispute between the city government of Surabaya and Gresik regency, beginning with Mr. Sabron Djamil activities Pasaribu Chairman of Commission A Java Parliament (2009-2014) and followed by other members of a commission with the inspection to Galang Island.

A commission at the time indicated there were irregularities in the issuance of a certificate on the ownership of Pulau Galang that seem to protect the owner of the certificate, as is evident from the entry Galang Island, only controlled by the owner of warehousing, but there is no enforcement of the relevant institutions.

A commission has even come to consult the National Land Agency Galang Island, and the National Land Agency pledged to help revocation certificates owned by the third person, if found irregularities at the time of publication.

Special Committee Java DPRD ever discuss this dispute argues, BPN 
and local government have violated procedures Gresik new island ownership, no decision has been facilitated by the authorized institutions sold and ended up in the hands of investors. Then all the buying and selling was null and void, the certificate should be revoked. On the administrative control of the islands should have been charged to the Provincial Government of East Java as an arm of the central government, and employers should not be arbitrarily reclaiming the islands.

Finally the Special Committee recommends that the Parliament of East Java East Java Governor filed a revocation of certificates of property rights on Galang Island. ${ }^{7}$

f. East Java Government's argument

Through Mr. Supriyanto, SH., MH. Ka.Biro Public Administration and Governance, and PJ. Regent of Blitar, delivered to the problems that Galang Island in the fighting by the Surabaya and Gresik, is as follows:"East Java Governor, Soekarwo, in October 2013 sent a letter to the Minister of the Interior

${ }^{7}$ Interview with Kusnadi, SH., M.Hum former Acommission member of Indonesian Board of Assembly 0n 1 June 2015
(Home Affairs) concerning a dispute between local government Galang Island Gresik and Surabaya City Government. The letter in order to strengthen Galang Island status as a conservation area managed by the Provincial Government of East Java.

Np confirmation letter. 590/227 dated June 18, 2014 on Galang Island of Home Affairs, stated that the status management Galang Island submitted to the Provincial Government of East Java, while related matters Surabaya City Government property or otherwise Gresik regency 'status quo' and assigned to the Governor of East Java to facilitate and maintain conservation for environmental sustainability”. 8

The argument of some parties as mentioned above becomes a source of a struggle over control Galang Island, and it can be concluded that the source of conflict due to:

1. The issuance of the certificate of ownership 7 villagers of Karang Kiring Galang Island by land office in Gresik which eventually merged into a certificate issued

${ }^{8}$ Interview with General Department East Jave Province on 26 June 2015. 
by the Regional Office of BPN and Spatial East Java.

2. Reclamation conducted by PT. Gantari Sandya Partner GSM) has changed the regional boundaries and eliminate the livelihood of fishermen.

3. Ownership galang island by PT GSM development goals conflict with the central warehousing function space utilization, because in accordance with the mandate of the regional spatial plan (RTRW) jatim 2009-2029. The island's mangrove areas and the conservation of fauna.

In essence, the conflict created by competition for access to the authority (power) and economic resources / wealth of the actors concerned. ${ }^{9}$

Boundary disputes can cause horizontal conflicts and tend to be anarchic and destructive action among community members. Research boundary conflict between Tebo and Bungo in this study due to factors both

${ }^{9}$ Syamsul Hadi, et.al., 2007, Disintegrasi Pasca Orde Baru: Negara, Konflik lokal dan Dinamika Internasional, Yayasan Obor Indonesia, Jakarta, p.42

10 Nurbadri, 2008, Konflik Batas Wilayah diera Otonomi Daerah dan Upaya Penyelesaiannya judicial and non-judicial. Juridical factors, among others ambiguities border arrangements and lack of socialization. ${ }^{10}$ At this research area is the city of Surabaya and Gresik, the research team found a few things that the impact of the border conflict, whether they are positive or negative. As for the impact that we can describe as follows:

a. Negative impact

i. There was stagnation in outlining the problems of seizing ownership Galang Island in the village of Karang Kiring Government, District Kebomas, Gresik. Reef Village Government Kiring through his village head, Mr. Aslimun explaining that the village in terms of not having the authority to describe the problems Galang Island because it is handled directly by the central government and the

(Study kasus Konflik Batas Wilayah antara Kabupaten Tebo dengan Kabupaten Bungo, Jurnal Masalah-Masalah Hukum, Fakultas Hukum Universitas Diponegoro, Vol.37 No.4, p. 266-272 
Province. In this situation the village has proved a weakness formal borders, as only rely on the Map Krawangan and book Kretek village that in fact never reform despite drawing the map has changed because of the nature.

ii. The lack of evidence of formal boundaries at village level resulting in weak protection against delimitation based on local wisdom.

iii. Reclamation conducted by PT GSM causing fishermen around the region decreased even loss of income due to damage to the environment that affect the marine habitat.

b. Positive impact :

i. Village Head Reef Kiring mention the presence of Galang Island dispute these positive impacts for prudence in running the government administration main

$$
\begin{aligned}
& \text { village land } \\
& \text { administration. } \\
& \text { ii. Affirmation of village } \\
& \text { boundaries is very } \\
& \text { important to arrive at the } \\
& \text { level of village } \\
& \text { government, for the } \\
& \text { planning of mapping by } \\
& \text { the village needed to } \\
& \text { prevent disputes, } \\
& \text { especially concerning the } \\
& \text { renewal of coastal areas. }
\end{aligned}
$$

Set a limit on the area that the implications for the region as a management authority in the field is definitely not easy. Administration of the regional government is already running and growing ever since the birth of the Republic of the Indonesia (NKRI) and limits of juridical been set by the law establishing the respective regions, the facts determine the points physical limits by law the establishment of the area itself often causes problems between the regions concerned because it is not easy to agree on the points specified limits.

In fact, border conflict areas in East Java government is not a new phenomenon. In 2012, the Regional Development Planning Board (Bappeda) of East Java, have recorded at least four 
border conflicts that occurred. Recorded

3 border conflicts in East Java which one of them occurred on the border of East Java and Central Java, namely: The battle over the crater between Banyuwangi regency and Bondowoso regency; conflict between Rembang in Central Java and Tuban in East Java. This conflict fight quartz sand mine excavation; conflict between Blitar and Kediri Regency with regard to Kelud. ${ }^{11}$ Statement misunderstanding was believed as the underpinned reason of the conflict. $^{12}$

Rules and norms relevant to the conflict as the norm entitled to assign the results received by certain parties to also determine the aspirations of what they are entitled. When aspiration is considered incompatible with the purpose of other parties then the result can lead to conflict. ${ }^{13}$

Indonesia has a high potential for regional conflict and increased after the

\footnotetext{
${ }^{11}$ Ira Permata Sari, 2014, Konflik Perbatasan Pemerintah Daerah (studi kasus: perebutan gunung kelud antara pemerintah daerah Kabupaten Blitar dengan Kabupaten Kediri), Jurnal Ilmu Pemerintahan UB, 08 Januari 2014, p.3

${ }^{12}$ Nida Zidny Paradhisa, 2012, Konflik Kepentingan Daerah: Studi Kasus Sengketa Perebutan Gunung Kelud antara Pemerintah Kabupaten Kediri dan Pemerintah Kabupaten Blitar, Jurnal Politik Muda Universitas
}

regulation of regional autonomy. Before the era of regional autonomy, in Indonesia there are only 27 provinces and 277 districts / municipalities. After regional autonomy, that number swelled to 34 provinces and 511 districts / cities even more with the accelerated rate of expansion of the countless outstanding and, as expected, creating spaces of potential new problems. The division of a region into a number of new autonomous regions result in changes to the boundaries of the area region both administrative and geospatial (spatial), which is the essence of the emergence of serious problems. Those problems are conflicts over land boundaries. ${ }^{14}$

In practice, the process of conflict settlement boundaries cannot always be carried out smoothly, there is a tendency even number of disputes / conflicts boundaries between regions increases. From the practical point of view, identified some of the causes of

Airlangga, Vol 2 No.1, Januari-Maret 2012, p. 136-146.

${ }^{13}$ Dean G. Pruit \& Jeffrey Z Rubin, 2004, Teori Konflik Sosial (terjemahan), Pustaka Pelajar, Yogyakarta, Social Conflict: Escalation, Stalemate and Settlement, Mc. Graw-Hill In, p. 32

${ }^{14}$ Djoko Harmantyo, 2007. Pemekaran Daerah dan Konflik keruangan Kebijakan otonomi daerah dan Implementasinya di Indonesia, Makara, sains, vol. 11, No. 1, p. 16- 22 
conflicts related to boundaries of this region, among others:

1. Juridical aspect, namely the lack of clarity in the area boundary Formation of the Regional Law.

2. Economic aspect, namely Scramble Resources (SDA, Commercial Region / Transmigration, Plantation).

3. Culture aspect, namely the issue of the separation of ethnic or subethnic.

4. Politics and Demographics aspect, namely seizure of voters and the vote for the members of the Legislative / Executive.

5. Social aspect, namely the emergence of social envy, a history of past conflicts, the issue of indigenous peoples and migrants.

6. Government, namely the distance to the center of government, discrimination in services, the desire to join the neighboring areas. ${ }^{15}$

${ }^{15}$ Jembris Mou, Konflik Wilaya Antara Kabupaten Halmahera Utara dengan Kabupaten Halmahera Barat, Jurnal Politico Vol.2 No.6 Tahun 2015, p.3

${ }^{16}$ Brian Taylor Summer dalam Aditya Batara G \& Beny Sukadis, (Editor), 2007, Reformasi
Geographical and historical factors are two aspects of the other aspects that are often a reason for territorial claims. Geography (geography) is a classic claim based on natural boundaries, whereas history (history) is the determination of a claim based on history (the first possession) or duration (length of ownership). ${ }^{16}$

Thus, necessary legal instrument to solve the problems of this region boundaries is needed. Decentralization policies needed to be a resolution of the border conflict, by incorporating aspects strong locality as the "legal basis" argument will undoubtedly form the rules were very understanding wishes of the people involved in the conflict.

\section{Establishing authority in the village and Affirming Limits Areas Management \\ Reflecting the wide range of areas such as boundary disputes Blitar and Kediri, Surabaya and Gresik, things that need to be addressed further relevant authority is directly affected as a result of}

\footnotetext{
Manajemen Perbatasan di Negara-Negara Transisi Demokrasi, DCAF \& LESPERSSI, Jakarta, p. 52.
} 
the seizure of the village of the region. The policies issued has not been explicitly consider local knowledge as well as the evidence possessed by the community or village in dispute. This condition is also weakened by the village itself which are less likely to have evidence of a strong and resolute in the face of the law. The village does not have a legal product at their levels to strengthening borders, because the regulations on boundaries exist only at the lowest level in conjunction with the establishment of a local district.

So far, the government argues that the settlement boundary of the village is not the important thing and is not even becoming part of the development priorities. Regulation of the Minister of the Land Planning (hereinafter called Regulation) governing boundary demarcation areas include provincial and district boundaries, even though the village is a region that is in direct contact with the delimitation. If the village area is legally fixed, this automatically cause the certainty of both provincial and district boundaries.

The village only mentioned in general borders in a variety of settings that require entering the village profile, no special arrangements are periodically revised to update whether there are expansion of territory, while atural phenomena may change a territory geographically, especially areas prone to natural disasters. The data related to the area between the villagers who owned books $\mathrm{C}$ village which is an excerpt of tax payments, books and maps krawangan clove, all of which were never carried out reforms if there is a change related to natural changes.

Changes in nature that occur in the geographical conditions of rural areas should be followed by the recording of even mapping activities that can be done independently by the village. Although the demarcation area only became part of the district and provincial administrations, at the level of village administration should also be given to affirm the policy in managing its territory.

Constitutionally speaking government authority to the village, it can refer to the position of the village (or any other name), in Article 18B paragraph (2) of the 1945 Constitution which regulate: "The State shall recognise and respect their traditional communities along with their traditional customary rights as long as these remain 
in existence and are in accordance with the societal development and the principles of the Unitary State of the Republic of Indonesia, and shall be further regulated by law".

This constitutional provision means that:

a. Constitutionaly, there are differences between autonomy local government institutions from those of community

b. Matters managed by the local government unit shows the dispersion of power, while, as long as there, matters managed by the village of recognition.

c. There are also assistance task given by the District, Provincial and Central Government.

Territorial management at the village level is aimed to protect and affirm the limit and thus should be part of constitutionally recognized rights if upon such region a local wisdom exist.

Ownership conflict of Galang Islang which is contented between the Gresik and Surabaya according to Kadesh Karang Kiring, Mr. Aslimun,

${ }^{17}$ Interview with Village Chief Karang Kiring on 27 Agustus 2015 one reason is the loss of recognition historically local knowledge possessed by Karang Kiring, as an example of the mastery of the area which includes the existence of the port in The village has actually been around since the reign of Majapahit, but the recognition of the right to development is lost, as does the presence of Galang Island are historically used to blend with the village of Karang Kiring. ${ }^{17}$

Another disadvantage according to Kadesh Reef Village Kiring is never update them to the changes that occur geographically due to natural phenomena, the village does not have a map that periodically made to anticipate change. The difficulties experienced by the village of Karang Kiring in terms of proving the management of the region, especially with regard to the use of marine space. Karang Kiring have land and the area immediately adjacent to the sea. Phenomena and natural phenomena that occur at sea causing changes in the region, such as erosion. These circumstances make it difficult for villagers to make a claim against the utilization of space, although hereditary 
community already utilize this marine resource, but often they were beaten by the investor-financier stronger access to the Government. ${ }^{18}$

In the case of seizure of Galang Island, not only questioned the authority of the ownership between the district and the city, but the control by employers against this Galang Island also cause horizontal conflicts associated with the interests of fishing communities in the village of Karang Kiring. Employers in this case PT GSM concerned to increase the economic value of the resources in the agrarian Galang Island has conducted reclamation. Reclamation activities conducted by PT GSM resulted in environmental damage and cause a reduction in the fishing village of Karang Kiring results and this threatens their livelihoods.

Boundary conflicts can be regarded as problems in the use of space, especially in terms of allocation of natural resources there. Local residents in need of natural resources as a source of life for the continuation of their lives. While investors who have the purpose of obtaining maximum profits tend to do whatever it takes to master the allocation of these resources.

Minister Regulation No. 76 Year 2012 on Guidelines of Region Emphasis (hereinafter referred to as Regulation 76/2012) specifies that the border of the provinces or districts under Article 1 paragraph (3), (4) and (5) are:

1. Limit the area of land is a limiting administrative area between regions is a series of coordinate points that are on the earth's surface can be natural signs such as igi /the ridges /mountains (watershed), the median stream and / or elements of artificial field poured in the form of maps.

2. Limit the area of the sea is the limiting authority in marine resource management for the area in question is a series of coordinate points measured from the coastline.

3. Limits for certain regions in the field is a set of geographical coordinates of points that refer to national georeferencing system and establish administrative area boundary line between regions.

${ }^{18}$ Ibid 


\author{
The assertion border under \\ Article 1 paragraph (6) Regulation \\ $76 / 2012$ \\ "The assertion is an activity area \\ boundary determination coordinate \\ points of the border to do with the \\ method kartometrik and / or surveys in \\ the field, which is manifested in a \\ boundary map with a list of coordinates \\ of the boundary points of the area." \\ Stages affirmation limit set in \\ Article 5 of Regulation 76/2012, among \\ others: \\ a. document preparation; \\ b. Tracking the limit; \\ c. measurement and positioning \\ limits; and \\ d. mapmaking limits;
}

These stages are more focused on the technical work mapping, but for this assertion involving the parties will agree on the claims over the territory so as to have a high potential for conflict. The agreement requires the parties social peace, calm and mutual respect, and usually local wisdom on this process is condensed in rural communities that uphold the principles of mutual cooperation and consensus. Thus the assertion of this limit becomes more efficient when done based on local wisdom directly adjacent to the main village and local community involvement.

Conflict limit even involve not only between the two areas of the province or district / city, even at the level of indigenous peoples across subdistricts are also experiencing the same thing. As in the community and society Pingai Muaro Nagari Nagari Saningbakar Solok regency, the following: "In anthropological disputes that occur in Minangkabau society is an expression of the inherent contradictions and incompatibility of a culture that has been patterned based on opposite interests, which arise from the structure of society itself. Boundary disputes customary villages between villagers 'Muaro Pingai the District uphold Betel and villagers' Saningbakar the District $\mathrm{X}$ Koto Singkarak is solved by means of deliberation of the traditional leaders of the two villages were solved by Muspika both districts, and subsequent settlement 
submitted to the District Government Solok."19

The assertion boundary area management at the village level as well as the Village People in the mirror at persolaan among people Minangkau thus becomes essential, it does require an agreement framed in a formal setting at the level of the village or the Village People. The enactment of Act No. 6 of 2014 on Village (hereinafter referred to as the Village Act) and its implementing regulations in Government Regulation No. 43 of 2014 (hereinafter abbreviated as PP 43/2014) became the legal basis of the argument in the form of regulations at the village level affirmation borders.

Powers stipulated in the Act allow the village to provide protection for the village over its territory, it will certainly minimize conflicts / disputes the border. Article 18 of the Law Village gives provisions that: "The authority of the village include the authority in the field of implementation of village government, the implementation of Rural Development, Rural community development, and community

${ }^{19}$ Zusmelia MS, 2011, Peneyelesaian Sengketa Batas Ulayat Nagari antara Masyarakat Nagari Muaro Pingai dan Masyarakat Nagari Saningbakar Kabupaten Solok, Jurnal Hukum empowerment village based community initiatives, the right of origin, and customs of the village". The fourth field is the authority given to the village is expected to make a strong village, developed, independent and democratic. In accordance with Article 19 of Law Village fundamental changes to the authority of the village administration currently include:

a. The authority of origin based rights;

b. Village-scale local authority;

c. The authority assigned by the Government, Provincial Government, or the Regional Government of Regency / City; and

d. Other authorities assigned by the Government, Provincial Government, or the Government District / City in accordance with the provisions of the legislation.

Article 18 and Article 19 of the Law on the Village has been set and determine what kind of authority at the village level, among other authorities in

Republica, Vol.10 No.2, Fakultas Hukum Universitas Lancang Kuning. 
the care and regulated by the Village and authority in the care of just by the village but was assigned by the government both at central and local levels. Article 6 of the Regulation of the Minister of Internal Affairs ear 114 numbers 2014 on Guidelines for Rural Development (hereinafter referred to as Regulation $114 / 2014$ ) provides that in carrying out the construction of the village, the village government should refer to RPJMDesa (Rural Medium Term Development Plan) which includes Vision Mission Village Head and direction rural development policy. Article 6 provides guidance on the village to hold the administration in villages based powers who owned the village.

Direction of rural development guidelines in the areas of governance based on Article 6 paragraph (2) letter a Regulation $114 / 2014$ is the "Establishment and Assertions Village Limits". This provision provides protection against the village on its territory, thus it should be after the birth village Village Act prioritizes the direction of its development policy to make the determination and demarcation village first.
Determination and confirmation of village boundaries is done not only as a resolution to the conflict, but become important when the village is also required to prepare and establish the Spatial Plan Village integrated into rural areas, as regulated in Article 83 of Law Village, with the following conditions :

(1) Development of Rural Areas is a mix of inter-village development in one (1) District / City.

(2) Development of Rural Areas implemented in an effort to speed up and improve the quality of service, development, and empowerment of villagers in Rural Areas through participatory development approach.

(3) Development of Rural Areas include:

a. use and utilization of the Village area in the establishment of spatial development in accordance with the Regency / City;

b. services are being made to improve the welfare of rural communities;

c. infrastructure development, improvement of the rural economy, and the 
development of appropriate technologies; and

d. The village community empowerment to improve access to services and economic activities.

(4) The design of the construction of Rural Areas discussed jointly by the Government, Provincial Government, District Government / City and Village Government.

(5) Rural Area development plan referred to in paragraph (4) shall be determined by the Regent / Mayor in accordance with the Medium Term Development Plan.

The obligation to carry out development of rural areas following further stipulated in Article 123 Paragraph (2) (b) of Government Regulation No. 43 Year 2014 concerning the Implementation Regulations Act Rural (hereinafter abbreviated as PP 43/2014), as follows: "Development of rural areas consist of the preparation of

\footnotetext{
${ }^{20}$ Ahmad SJA, dkk, 2009, Menuju Demokratisasi Pemetaan (Refleksi Gerakan Pemetaan
}

spatial planning in a participatory rural areas".

Authority related to development of rural areas should have been preceded with certainty village in providing a guarantee of protection against the territory. For the establishment and affirmation of village boundaries become important primarily to avoid or resolve conflict zone management.

To support the strengthening of legally to guarantee legal certainty for the region, both at the level of the village and the village should have done the mapping is done in a participatory manner. Participatory mapping will certainly adjust to the real conditions in the region. ${ }^{20}$

The participatory mapping (hereinafter called PM) has two components, which include mapping and participatory nature. The following will explain the meaning of those two components. Determinantion of territorial demarcation and delimitation through participatory mapping is necessary to achieve legal certainty, whereas:

Partisipatif di Indonesia), JKPP (Jaringan Kerja Pemetaan Partisipatif), Bogor, p. 4 
1. Participatory mapping upon the village territory will assure local community's rights and its assets.

2. Participatory mapping upon district territory which is envisaged within "Decision of City Major” will also assuring the certainty of territorial borders.

Participatory action of Village

Government in determining its territorial borders is crucial to avoid possible conflict between local region and between community, government and business entity.

\section{CONCLUSION}

Borders conflict over the Galang Island has caused both vertical as well as horizontal conflict, that is between the fishermen and private entity given the right to manage the island. The lack of formal evidence at the village level leads to the weakness of legal protection of local wisdom.

The certainty in borders delimitation is important to be conducted until village level by planning a participatory mapping based on local wisdom accommodating possible natural changes of such territory. The authority of Village Government in determining territorial delimitation should be recognized constitutionally as stated within Indonesian Act No. 6/ Year 2014 and Permendagri 114 Year 2014.

\section{REFERENCES}

Ahmad SJA, dkk, 2009, Мепuju Demokratisasi Pemetaan (Refleksi Gerakan Pemetaan Partisipatif di Indonesia), JKPP (Jaringan Kerja Pemetaan Partisipatif), Bogor.

Brian Taylor Summer dalam Aditya Batara G \& Beny Sukadis, (Editor), 2007, Reformasi Manajemen Perbatasan di Negara-Negara Transisi Demokrasi, DCAF \& LESPERSSI, Jakarta.

Dean G. Pruit \& Jeffrey Z Rubin, 2004, Teori Konflik Sosial (terjemahan), Pustaka Pelajar, Yogyakarta, Social Conflict: Escalation, Stalemate and Settlement, Mc. Graw-Hill In.

Djoko Harmantyo, 2007. Pemekaran Daerah dan Konflik keruangan Kebijakan otonomi daerah dan Implementasinya di 
Brawijaya Law Journal V.3 n.2 Contemporary Indigeneous and Constitutional Issues

Indonesia, Makara, sains, vol. 11, No. 1.

Ira Permata Sari, 2014, Konflik Perbatasan Pemerintah Daerah (studi kasus: perebutan gunung kelud antara pemerintah daerah Kabupaten Blitar dengan Kabupaten Kediri), Jurnal Ilmu Pemerintahan UB Edisi 08 Januari 2014.

Jembris Mou, 2015, Konflik Wilaya

Antara Kabupaten Halmahera

Utara dengan Kabupaten

Halmahera Barat, Jurnal Politico

Vol.2 No.6 Tahun 2015

Nida Zidny Paradhisa, 2012, Konflik Kepentingan Daerah: Studi Kasus Sengketa Perebutan Gunung Kelud antara Pemerintah Kabupaten Kediri dan Pemerintah Kabupaten Blitar, Jurnal Politik Muda Universitas Airlangga, Vol 2 No.1, Januari-Maret 2012

Nurbadri, 2008, Konflik Batas Wilayah diera Otonomi Daerah dan Upaya Penyelesaiannya (Study kasus Konflik Batas Wilayah antara Kabupaten Tebo dengan Kabupaten Bungo, Jurnal Masalah-Masalah Hukum,
Fakultas Hukum Universitas Diponegoro, Vol.37 No.4.

Syamsul Hadi, et.al., 2007, Disintegrasi Pasca Orde Baru: Negara, Konflik lokal dan Dinamika Internasional, Yayasan Obor Indonesia, Jakarta.

Zusmelia MS, 2011, Peneyelesaian Sengketa Batas Ulayat Nagari antara Masyarakat Nagari Muaro Pingai dan Masyarakat Nagari Saningbakar Kabupaten Solok, Jurnla Hukum Respublica, Vol.10 No.2, Fakultas Hukum Universitas Lancang Kuning.

http://www.publiknasional.com/index.p hp?option=com_content\&view= $\underline{\text { article\&id=1464: } \text { uruk-pantai-pt- }}$ gantari-sandya-mitra-diprotresnelayan\&catid=36:jawa-timur, diakses pada 27 Mei 2015

Undang-Undang Dasar 1945

Undang-Undang Nomor 6 Tahun 2014 tentang Desa

Undang-Undang Nomor 23 Tahun 2014 tentang Pemerintahan Daerah

Peraturan Pemerintah Nomor 43 Tahun 2014 Tentang Peraturan Pelaksanaan UU Nomor 6 Tahun 2014 Tentang Desa 
Brawijaya Law Journal V.3 n.2 Contemporary Indigeneous and Constitutional Issues

Peraturan Menteri Dalam Negeri Nomor

114 Tahun 2014 tentang

Pedoman Pelaksanaan

Pembangunan Desa 